\title{
SYMPOSIUM ON SIMON BATIFORT AND J. BENTON HEATH, “THE NEW DEBATE ON THE INTERPRETATION OF MFN CLAUSES IN INVESTMENT TREATIES: PUTTING THE BRAKES ON MULTILATERALIZATION"
}

\section{THE FICTIONS AND REALITIES OF MFN CLAUSES IN INTERNATIONAL INVESTMENT AGREEMENTS}

\author{
Facundo Pérez-Ažnar*
}

In an article published concurrently in the Journal of International Economic Law, ${ }_{1}^{1}$ reach many of the same conclusions as Simon Batifort and J. Benton Heath ${ }^{2}$ regarding the use of most favored nation (MFN) clauses to import substantive provisions from other treaties. However, although our conclusions are similar, our reasoning differs in several important respects. In my view, the reasons why MFN clauses cannot be used to import treaty provisions have more to do with the nature of these clauses than their specific text. MFN clauses are primary rules that require performing a comparison and determining whether there is a breach of the provision, and this produces legal effects that run against any attempt at importation. In addition, it is not possible or desirable to interpret MFN clauses in isolation from general international law. Stephan Schill ${ }^{3}$ is also correct that Batifort and Heath cannot disclaim the normative implications of their effort to shift the debate over MFN clauses. But Schill confuses the legal effects of MFN clauses with a policy consideration (multilateralization) and misreads the interpretative background that must be considered when applying MFN clauses. Schill also mistakes multilateralization via arbitral interpretations of MFN clauses for true multilateralism, which is the product of states working together in multilateral fora. That distinction matters, too, for Schill's solution might provoke a state-led backlash that will undermine the very multilateralism he seeks to promote.

\section{The Nature of MFN Clauses}

My main disagreement with Batifort and Heath is that they associate any consideration of the nature of MFN clauses with the so-called "top-down" approach and "see little reason to approach MFN provisions in investment treaties with a preconceived notion of the essential purpose or nature of these provisions." ${ }^{\prime 4}$ In my view, it is mainly

* Senior Researcher, Geneva Center for International Dispute Settlement, Switzerland; Associate Professor of International Economic Law, University of Buenos Aires, Argentina.

${ }^{1}$ Facundo Pérez-Aznar, The Use of Most-Favoured-Nation Clauses to Import Substantive Treaty Provisions in International Investment Agreements, 20 J. INT'L ECON. L. 777 (2017).

${ }^{2}$ Simon Batifort \& J. Benton Heath, The New Debate on the Interpretation of MFN Clauses in Investment Treaties: Putting the Brakes on Multilateralization, 111 AJIL 873 (2018).

${ }^{3}$ Stephan W. Schill, MFN Clauses as Bilateral Commitments to Multilateralism: A Reply to Simon Batifort and J. Benton Heath, 111 AJIL 914 (2018).

${ }^{4}$ Batifort \& Heath, supra note 2 , at 886 ; see also id. at 877-78, 882, and 886.

\footnotetext{
The American Society of International Law and Facundo Pérez-Aznar (C) 2018. This is an Open Access article, distributed under the terms of the Creative Commons Attribution licence (http://creativecommons.org/licenses/by/4.0/), which permits unrestricted reuse, distribution, and reproduction in any medium, provided the original work is properly cited.
} 
because of the nature of MFN clauses that they cannot be used to import treaty provisions. I agree that a textual analysis of MFN clauses may allow one to reach a similar conclusion, but that conclusion will be incomplete if we do not also take into account the nature of these clauses.

MFN provisions are both substantive standards that require performing a comparison and primary rules that require determining whether there has been a breach of the provision. ${ }^{5}$ This is a distinction that is often disregarded in the literature and in arbitral decisions interpreting MFN clauses in international investment agreements (IIAs). In addition, there is a close relationship between MFN and national treatment (NT) clauses, which evidences their common nature. This has been recognized by states, investment tribunals, and the International Law Commission (ILC). ${ }^{6}$ Recently, the ILC's Study Group on MFN, which addressed the interpretation of MFN clauses in IIAs, noted that "interpretations of phrases such as 'in like circumstances' or 'in similar situations' in the context of national treatment can provide important guidance for the interpretation of those terms in the context of MFN clauses." 7

The nature of MFN clauses implies that they grant better treatment and failure to grant that treatment constitutes a treaty breach. That is the view of the arbitral commission in Ambatielos, the World Trade Organization dispute settlement bodies, and the ILC. 8 The Draft Articles on Most-Favoured-Nation Clauses adopted in 1978 by the ILC confirmed that the rules contained therein were "primary rules" and that "any violation of an obligation under a most-favoured-nation clause, whether such violation has been committed directly or indirectly, by circumvention of the obligations concerned, will entail the international responsibility of the granting State."

This approach was endorsed in the context of the North American Free Trade Agreement by the ADF v. United States tribunal. ${ }^{10}$ The tribunal determined that, due to the exceptions provided for in Article 1108, the MFN clause in Article 1103 did not apply to government procurement by a contracting state. However, the tribunal set out some useful guidelines when invoking provisions from another treaty through an MFN clause that reflect the general rules surrounding the nature of MFN clauses and that may be useful to other tribunals. The tribunal considered that the claimant first "ha[d] not been able persuasively to document the existence of such autonomous standards," i.e., that the "fair and equitable treatment" (FET) and "full protection and security" clauses in the invoked treaties established standards of treatment distinct from the specific requirements of customary international law. Second, the claimant had not shown that "the U.S. measures are reasonably characterized as in breach of such standards." Third, the tribunal added that "the investor still has not thereby shown violation of Article 1103 by the Respondent." Finally, it suggested that the investor had to "demonstrat[e] the 'more favourable' nature of the [invoked] treaty provisions." These statements reflect the tribunal's view that in order to apply an MFN clause to treatment granted by other treaties it is necessary to interpret all the elements of the clause (i.e., taking into account the text of the clause) and ultimately find a breach of it (i.e., taking into account the nature of the clause).

My second point of disagreement with Batifort and Heath is that they disregard the importance of finding a breach of the MFN clause, even though they quote some relevant state practice and literature in this regard. The need to establish a breach has important consequences for the application of MFN clauses to treatment granted by other treaties. First, it is not possible to use MFN clauses to import or amend provisions, either substantive or jurisdictional, simply because this is not the function of a primary rule that requires performing a comparison and

\footnotetext{
${ }^{5}$ Pérez-Aznar, supra note 1, at 788-89.

${ }^{6} I d$.

${ }^{7}$ Int'l Law Comm'n, Study Group on the Most-Favoured-Nation Clause, Final Report, UN Doc. A/CN.4/L.852, at 19, para. 77 (2015).

${ }^{8}$ Id. at $791-95$.

${ }^{9}$ Int'l Law Comm'n, Draft Articles on Most-Favoured-Nation Clauses, 2 Y.B. InT'L L. Comm'n 16, 71, art. 27 cmt. paras. 2 and 4 (1978).

${ }^{10}$ ADF Group Inc. v. U.S., ICSID Case No. ARB(AF)/00/1, Award, paras. 194-97 (Jan. 9, 2003).
} 
determining whether there is compliance with it. Second, a breach of an MFN clause entails the international responsibility of the wrongful state and, consequently, the general principles of reparation enter into play, including the need to establish a causal link between the wrongful act and the injury, as well as the question of mitigation damage. ${ }^{11}$ This would imply in practical terms that, for example, a tribunal cannot establish damages for a breach of an MFN clause equivalent to a breach of a substantive provision not included in the treaty (e.g., FET).

\section{The "External" Context of MFN Clauses}

I also disagree with Batifort and Heath's view that, when interpreting an MFN clause, there is a dichotomy between the text and the nature of these clauses. ${ }^{12}$ No doubt any treaty interpretation must be based above all on its text. But in my view, a correct interpretation of an MFN clause (as with any other treaty provision) has also to take into account the nature of the provision. I share Schill's observation that Batifort and Heath, by focusing on a treaty-by-treaty analysis, appear to disregard other interpretative elements, and that "the interpretation of MFN clauses in IIAs is never isolated from general international law." 13 However, I am skeptical of Schill's endorsement of the use of (multilateralizing) "presumptions." 14 Rather than conventional wisdoms or presumptions, an interpreter should apply "rules of international law."

The "general rule of interpretation" provided for in Article 31 of the 1969 Vienna Convention on the Law of Treaties (VCLT) includes "any relevant rules of international law applicable in the relations between the parties." This is part of the so-called "external" context referenced in Article 31(3). That external context implies that, in addition to the text and internal context of the provision, the interpreter must pay attention to general principles of law (such as good faith or effectiveness), customary international law (such as rules on state responsibility), and principles of international law (such as the principle of consent to international jurisdiction). In my view the nature of MFN clauses and the ejusdem generis rule fall under the category of "relevant rules of international law." Tribunals and scholars, however, very often disregard these rules when interpreting MFN clauses (in addition to disregarding their text).

I agree with Batifort and Heath's view that the prevailing approach in investment arbitration with regards to the importation of substantive provisions through MFN clauses is founded on "conventional wisdom" based on "presumptions as to the nature or essence of MFN clauses in general." " I I disagree with Schill's view that the prevailing approach in investment cases dealing with importation of substantive provisions starts from a treaty-by-treaty approach that accords principal weight to the interpretation of individual MFN clauses. ${ }^{16}$ Arbitral decisions show rather the opposite. As it happened in the context of decisions involving the alteration of jurisdictional provisions in IIAs through MFN clauses, the analysis of MFN clauses in the context of importation of substantive provisions has depended less on the specific terms or context of the treaty at issue than on the tribunal's presumptions concerning the scope and effect of these clauses. Actually, from a total of fourteen cases that I have analyzed where the tribunals allowed the importation of substantive provisions, in nine cases there was no analysis of the text of the MFN clause whatsoever and the tribunals proceeded to directly import the invoked provisions. In only five of these fourteen cases did the tribunals perform an analysis of some of the elements of the MFN clauses, and

\footnotetext{
${ }^{11}$ Pérez-Aznar, supra note 1, at 801-03.

${ }^{12}$ Id. at $889,908$.

13 Schill, supra note 3 , at 923 .

${ }^{14}$ Id. See also id. at $917,922$.

${ }^{15}$ Batifort \& Heath, supra note 2, at 874.

${ }^{16} \mathrm{Id}$. at 916.
} 
those that did overlooked key elements of the MFN provisions, such as references to "similar situations" or to treatment in the "territory."

When interpreting an MFN clause, an investment tribunal should perform a textual analysis of the clause, paying attention to all its elements and taking into account its internal and external context, in accordance with the VCLT. Whichever treatment an investor invokes under an MFN clause (by an internal measure or by an international agreement), it cannot escape the application of each element of the clause, and, ultimately, a determination of whether there has been a breach of the provision.

\section{The Effects of MFN Clauses and Policy Considerations: Actual Discrimination v. Multilateralization}

I agree with Batifort and Heath that when including MFN clauses in their IIAs, states did not envision that these provisions would import standards of treatment but rather contemplated that they would forbid actual discrimination by the host state. ${ }^{17}$ At the same time, it is true that, their wording permitting, MFN clauses apply to more favorable treatment that the granting state extends to third states and their subjects, including investors, in international agreements. ${ }^{18}$ But this is not equivalent to the "importation" of provisions. ${ }^{19}$ What a tribunal should do is compare the treatment of the claimant under the base treaty with the treatment of investors under the referenced treaty and, if appropriate, make a finding that the MFN clause has been breached.

Under this framework, the argument that MFN clauses are bilateral commitments to multilateralization ${ }^{20}$ becomes a "legal fiction." Multilateralism describes an approach to foreign relations that seeks cooperation with other states and manifests in diplomacy, negotiation, international conferences, the conclusion of treaties, and the formation of international organizations. John Jackson noted that multilateralism and MFN were two different concepts, and that the former was a "policy argument" that underpins the latter. ${ }^{21}$

Multilateralism is based on the cooperation of states, not on a single provision included in a bilateral agreement nor in the decision of an ad hoc arbitral tribunal. The argument of multilateralization through MFN clauses does not refer to true multilateralism, but rather to the imposition of rules through arbitral decisions invoking MFN clauses. Under the multilateralization argument, the true agents of multilateralism, i.e., states and international organizations, are replaced by ad hoc tribunals. In addition, if MFN clauses were multilateralization devices, one would at least expect clearer language in this regard.

The multilateralization argument is reminiscent of the argument of "harmonization" through MFN clauses adopted by the tribunal in Maffezini. ${ }^{22}$ Other scholars have noted that contracting parties in IIAs are more concerned with granting protection to specific investors than in harmonizing and that it would be wrong for a tribunal to use the harmonizing argument as a reason to adopt particular interpretations of MFN clauses. ${ }^{23}$ Further, since an MFN clause operates when it is invoked by one particular investor concerning a particular investment and

${ }^{17}$ Id. at 909.

${ }^{18}$ Schill, supra note 3 , at 916 .

${ }^{19}$ Schill may have changed his views as regards importation through MFN clauses. See $i d$. at 914, n.5. Cf. STEPHAN W. SCHILL, The Multilateralization of International Investment Law 123 (2009) (“An investor covered by a BIT with an MFN clause can, therefore, invoke the benefits granted to third-party nationals by another BIT of the host State and directly import them into its relationship with the host State."); $i d$. at 143 ("Importing more favorable substantive conditions granted in third-country BITs comports with the economic rationale of MFN clauses.").

${ }^{20}$ See, e.g., Schill, supra note 3, at 922.

21 John H. Jackson, The World Trading System 158 (1997).

22 Maffezini v. Spain, ICSID Case No. ARB/97/7, Decision on Objections to Jurisdiction, para. 62 (Jan. 25, 2000).

23 Okezic Chukwumerije, Intrepreting Most-Favoured-Nation Clauses in Investment Treaty Arbitrations, 8 J.WorLd Inv. \&TRADE 597,611 (2007). 
requesting one particular treatment, harmonization through MFN clauses would be piecemeal and ad hoc, ${ }^{24}$ and would create both disharmony and an infinite array of treatments. ${ }^{25}$ These considerations apply equally to the multilateralization argument.

No doubt MFN clauses could contribute to the creation of truly multilateral frameworks, since one of the objectives of such clauses is to create an incentive for states to grant more favorable treatment. But this is an indirect consequence of, rather than the legal effect of, MFN clauses. However, arguments on importation or multilateralization through MFN clauses may produce the opposite effect: states react to these approaches by concluding more narrowly drafted MFN provisions or by distrusting the entire international investment regime.

This brings me to the issue of political ideology raised by Batifort and Heath and by Schill. Schill considers that Batifort and Heath's strict treaty-by-treaty approach to interpreting MFN clauses "is anything but ideologically neutral .... On the contrary, [their] approach would replace one ideology of, or vision for, international investment governance, namely that of ordering international investment relations on the basis of multilateral considerations and the principle of non-discrimination, with another." 26 This highlights the fact that the multilateralization argument is also an ideology of international investment governance and, consequently, does not resolve whether a particular ideology should be applied when interpreting MFN clauses.

I agree with Schill on the importance of defending and reinforcing multilateral regimes and multilateral cooperation structures. ${ }^{27}$ But multilateralizing through MFN clauses may actually be contrary to these goals. Multilateralizing through MFN clauses would imply a switch from multilateral or bilateral treaty-making to ad hoc modes of governing international economic relations that could have dramatic effects on the stability of the investment protection regime. It is for this reason that a truly multilateral transformation of the structures in international investment governance should be made through treaty-making and not through arbitral reinterpretations of IIAs.

The use of MFN clauses to automatically incorporate stipulations from other treaties has long been recognized as a "legal fiction." 28 Resorting to legal fictions can be useful in order to understand the policy implications of a legal concept. However, using a legal fiction to replace the "real" legal effect of a particular rule can undermine not only the application of the rule but the context where this rule is contained. In my view, this is the case of the multilateralizing presumption argument: it is a legal fiction that may do more harm than good. In order to properly apply MFN clauses in IIAs - and ultimately to avoid many of the usual criticisms of the international investment regime-it is necessary that scholars and tribunals distinguish the legal fictions from the real rules that apply to MFN provisions. The perceived legitimacy of the investment protection regime depends to a great extent on not conflating policy considerations in the interpretative process.

\footnotetext{
${ }^{24}$ Ruth Teitelbaum, Who's Afraid of Maffezini?: Recent Developments in the Interpretation of Most Favored Nation Clauses, 22 J. INT'L ARB. 225,226 (2005).

${ }^{25}$ Meg Kinnear, A Further Update on Most-Favoured-Nation Treatment_In Search of a Constant Jurisprudence, in CONTEMPORARY Issues IN International Arbitration and Mediation 15, 17 (Arthur W. Rovine ed., 2010).

${ }^{26}$ Schill, supra note 3 , at 934 .

27 Id. at 935 .

${ }^{28}$ Georg Schwarzenberger, The Most-Favoured-Nation Standard in British State Practice, 22 BRITISH Y.B. INT'L L. 96,104 (1945).
} 